copies of the original Russian editions can be found in four places in this country, including the Library of Congress and the New York Public Library (though there are none, apparently, in Britain). And the incomplete, secondhand (and anonymous) English translation printed here is the same one that was first printed in the second volume of F. C. Weber, The Present State of Russia (London, 1722), and reprinted in 1968 in the Da Capo/Frank Cass series. Thus it is hard to support Butler's claim that he has "discovered" or "rediscovered" something here.

In other words, though useful and convenient, this book is neither a scholarly edition of the "Razsuzhdenie" nor a scholarly translation of the complete original text. In view of these considerations, and the book's price, one must conclude, a little sadly: caveat emptor.

JAMES CRACRAFT

University of Illinois, Chicago

\title{
POLITISCHE UND GESELLSCHAFTLICHE VORSTELLUNGEN IN DER AUFSTANDSBEWEGUNG UNTER PUGACEV (1773-1775). By Dorothea Peters. FORSCHUNGEN ZUR OSTEUROPÄISCHEN GE- SCHICHTE, vol. 17. Osteuropa-Institut an der Freien Universität Berlin, Historische Veröffentlichungen. Berlin: Otto Harrassowitz, 1973. 364 pp. DM 78, paper.
}

Although this important synthesis appeared in West Germany when the USSR was celebrating the bicentennial of the Pugachev revolt, it was actually finished five years earlier. The author was able to use such works published in 1966-68 as those of Mavrodin, Andrushchenko, and Rozner in Russian and Paul Dukes and Marc Raeff in English. But the reader may find it difficult to appraise the book fairly if he has already familiarized himself with more recent publications in Russian or English, by writers such as J. T. Alexander and R. E. Jones.

But certainly if one thinks in terms of 1968 , this book offers many new facts and conclusions of great value to those who are interested in Russian history but have not made a special study of the literature in Russian on the topic. Its aim is not to retrace the course of the revolt; of which it makes only passing mention, but to define the chief characteristics and above all the viewpoints of those concerned: the rebels, the possessing classes, the government, and its leaders. Putting the question thus, the author was compelled to bypass it in a discussion of previous interpretations (in her historiographical introduction) and to end with conclusions integral in a certain philosophy of history, since all studies in the USSR have been guided by Marxist methodology.

In regard to the rebels, the conclusion is that theirs was not a truly revolutionary movement, because they had no objective clearly defined in advance. It was a heterogeneous assemblage of malcontents who, rather than having a vision of the future, often expressed the desire to return to a generally idealized past. The only element of unity was provided by Pugachev himself, who was content to promise in concrete terms to each segment of his followers what it more or less consciously desired. The Iaik Cossacks, who formed the initial nucleus of the rebellion, aspired to regain their prerogatives and were deeply divided into privileged and poor; the other Cossacks disappointed the hopes Pugachev placed in them. The peasants, who at the end made up the most numerous element, were protesting against the economic and legal oppression which grew ever more onerous: the serfs against 
that of the boyars, the state peasants against that of the local officials. The workers of the Ural factories were mostly uprooted peasants who were revolting against their employers and wished again to live and work in the countryside. As for the minorities, their aims were very specific and sometimes not in harmony with those of their fellow insurgents: the Bashkirs, who were the most active, blamed all Russians for the harm done to their national and religious rights and their traditional ways (nomadic life, freedom from recruitment, and so forth). Seeking to take advantage of all these discontents, Pugachev appears to the author, plausibly enough, as an opportunist attracted by adventure more than a utopian doctrinaire or a conscious revolutionary: he was a charismatic figure, using his own gifts of persuasion and the credulity of a people ready to submit blindly to the "true tsar."

Are things clearer or more rational on the side of the officials and the landowners? Indeed, everything shows that, with very rare exceptions (such as Sievers, governor of Novgorod), they did not understand or seek to understand the deep causes of the movement. After having underestimated the real importance of the rebellion, Catherine II and her advisers soon came to count on nothing-except for a few homilies unintelligible to the people-but brutal and widespread repression to restore calm. Instead of improving the condition of the people, they had in mind only strengthening the administration and making serfdom more rigorous. Even more, the nobility as an order (soslovie) behaved in a lamentable fashion; despite their eloquent pretensions to be the "shield of the throne and fatherland," they scarcely thought to do anything but take cover. Once order was restored by the army, the nobles usually forgot the last duty which they recognized toward their peasant laborers-that of patriarchal management.

Such are the conclusions of this solid and careful study. They rest on a vast and well-assimilated documentation, witnessed by abundant notes and a copious bibliography. They are reinforced by appendixes which, if they sometimes appear marginal to the subject, are always interesting in themselves. The most useful one shows that certain diplomats and foreign travelers in Russia were better informed about the events concerned than the great majority of the population, and understood better than the nobility the socioeconomic factors present in the revolt.

Michel LaRan

University of Paris

THE PETRAŠEVSKIJ CIRCLE, 1845-1849. By John L. Evans. Slavistic Printings and Reprintings, 299. The Hague and Paris: Mouton, 1974. 114 pp. 32 Dglds.

In his book Evans, through a conscientious use of the available sources, gives us a description of Petrashevsky's Fourierism, as well as Petrashevsky's views on his society and how to change it. He describes also the circle that met at Petrashevsky's residence and the social and political ideas of the circle members. He concludes with an account of the arrest, investigation, and punishment of the Petrashevtsy.

It is one of Evans's assumptions that Russia in the 1840s was, using Popper's category, a closed society which debased "the finer human qualities and led to the ruination of many of the outstanding Russian intellects of the period." This assumption, it seems, leads him to assert that the Petrashevtsy were entirely devoted to social justice and humanitarian ideals. He does not, to any significant degree, look for elements of self-interest in the social and political beliefs of the Petrashevtsy. He 